\title{
MANFAAT SERTIFIKAT TANAH SEBAGAI UPAYA PENERTIBAN ADMINISTRASI DI BIDANG PERTANAHAN
}

\author{
Abdul Mukmin \\ Dosen Fakultas Hukum Universitas Widya Gama Mahakam Samarinda
}

\begin{abstract}
ABSTRAK
Pendaftaran tanah merupakan persoalan yang sangat penting dalam UndangUndang Pokok Agraria (UUPA), karena pendaftaran tanah merupakan awal dari proses lahirnya sebuah bukti kepemilikan hak atas tanah. Dalam Peraturan Pemerintah Nomor 24 Tahun 1997 tentang Pendaftaran Tanah secara jelas dinyatakan tujuan yang hendak dicapai dengan adanya pendaftaran tanah tersebut, yaitu bagi masyarakat adalah untuk memberikan jaminan kepastian hukum atas bidang tanah yang di hakinya, sedangkan bagi pemerintah adalah untuk tertib administrasi pertanahan.
\end{abstract}

Kata Kunci : Sertifikat, Tertib Administarsi Pertanahan

\section{PENDAHULUAN}

Tanah yang ada di Indonesia pada umunya dikuasai oleh masyarakat Indonesia, akan tetapi secara yuridis (hukum) belum demikian. ${ }^{1}$ Melihat hal tersebut bahwa tidak semua masyarakat Indonesia yang memiliki dan menguasai tanah mempunyai hak kepemilikan atas tanah tersebut. Hal ini bukan hanya oleh masyarakat pedesaan tetapi juga masyarakat perkotaan, yang memiliki dan menguasai tanah namun tidak disertai kepemilikan sertifikat atas tanah yang dihakinya tersebut. ${ }^{2}$ Hal ini selain akan berdampak pada rawannya timbul sengketa pertanahan juga sangat menyulitkan pemerintah dalam menyediakan informasi di bidang pertanahan tersebut.

Undang-Undang Pokok Agraria (UUPA) Nomor 5 Tahun 1960, dalam pasal 19 merupakan dasar yang memberikan arahan dalam pembentukan dari Peraturan Pemerintah tentang pendaftaran tanah. Dalam pasal 19 tersebut dijelaskan mengenai tujuan dilaksanakannya pendaftaran tanah tersebut, yaitu untuk menjamin kepastian hukum oleh pemerintah serta untuk kepentingan negara (dalam hal administrasi) dan masyarakat, untuk keperluan lalu lintas sosial ekonomi. ${ }^{3}$

Kebutuhan akan tanah dewasa ini semakin meningkat sejalan dengan bertambahnya jumlah penduduk, jumlah badan usaha, dan meningkatnya kebutuhan lain yang berkaitan dengan tanah. Tanah tidak saja sebagai tempat bermukim, tempat untuk bertani tetapi juga dapat dipakai sebagai jaminan mendapatkan pinjaman di bank, untuk keperluan jual beli dan sewa menyewa. Begitu pentingnya kegunaan

\footnotetext{
${ }^{1}$ Sajuti Thalib, Hubungan Tanah Dengan Masyarakat Indonesia, Djambaran, Jakarta, 2004, hal 64

${ }^{2}$ Ibid

${ }^{3}$ P. Parlindungan, Pendaftaran Tanah Di Indonesia, Mandar Maju, Bandung, Cet I, 1999, hal 14
} 
tanah bagi orang atau badan hukum menuntut adanya jaminan kepastian hukum atas tanah tersebut. ${ }^{4}$

Dokumen-dokumen pertanahan sebagai hasil proses pendaftaran tanah adalah dokumen tertulis yang memuat data fisik dan data yuridis tanah bersangkutan. Dokumen-dokumen pertanahan tersebut dapat dipakai sebagai jaminan dan menjadi pegangan bagi pihak-pihak yang memiliki kepentingan atas tanah tersebut. Calon pembeli tanah atau calon kreditur merupakan pihak-pihak yang memiliki kepentingan atas tanah jika terjadi transaksi jual beli atau transaksi perkreditan. Tidak hanya calon pembeli dan kreditur, pemerintah juga sangat membutuhkan pencatatan atas tanah guna melaksanakan kebijakan pertanahan dengan tertib dan tidak tumpang tindih. ${ }^{5}$

Sertifikat hak atas tanah adalah produk pemerintah yang lahir karena hukum, dan bersifat konkret karena ditujukan untuk subyek dan obyek yang dapat ditentukan. Sertifikat atas tanah juga bersifat individual dan final, karena tidak ditujukan untuk masyarakat umum, akan tetapi hanya bagi mereka yang tercantum dalam sertifikat tersebut serta tidak memerlukan persetujuan dari instansi lain. Bila dilihat dari akibat yang ditimbulkan maka tindakan pemerintah dalam kegiatan pemberian setifikat hak atas tanah adalah bertujuan untuk menimbulkan keadaan hukum baru (recht sechpendde/constitutieve beschikking) sehingga lahir pula hak-hak dan kewajibankewajiban hukum baru terhadap orang atau badan hukum tertentu yang telah memiliki surat sertifikat hak atas tanah.

Dengan demikian, maka makna sertifikat sebagai alat pembuktian yang kuat dan bahwa tujuan pendaftaran tanah yang diselenggarakan adalah dalam rangka memberikan jaminan kepastian hukum di bidang pertanahan, serta terjaminnya tertib administrasi di bidang pertanahan menjadi tampak dan dirasakan artinya baik bagi masyarakat maupun pemerintah.

\section{RUMUSAN MASALAH}

Berdasarkan uraian yang telah penulis kemukan pada alasan pemilihan judul, maka dalam hal ini yang menjadi rumusan masalah dalam penelitian ini adalah sebagai berikut ;

1. Bagaimana Peran Pemerintah Dalam Menertibkan Sistem Pertanahan di Indonesia?

\section{TUJUAN PENELITIAN}

1. Untuk mengetahui mengapa tanah yang dihaki oleh masyarakat harus memiliki surat tanda bukti hak berupa sertifikat.

2. Untuk mengetahui bagaimana upaya yang dilakukan oleh pemerintah dalam menertibkan sistem pertanahan di Indonesia.

\footnotetext{
${ }^{4}$ Florianus SP Sangsun, Tata Cara Mengurus Sertifikat Tanah, Visimedia, Jakarta, 2007, hal 1

${ }^{5}$ Ibid, hal 2
} 


\section{METODOLOGI PENELITIAN}

\section{A. Jenis Penelitian}

Jenis penelitian yang digunakan adalah metode penelitian Yuridis Normatif yaitu penelitian yang dilakukan dengan cara meneliti bahan pustaka yang merupakan data primer atau yang lebih dikenal dengan penelitian kepustakaan. ${ }^{6}$

Karakteristik utama penelitian hukum normatif dalam melakukan pengkajian hukum adalah $;^{7}$

1. Sumber utamanya adalah bahan hukum bukan data atau fakta sosial, karena dalam penelitian hukum normatif yang dikaji adalah bahan hukum yang berisi aturanaturan yang bersifat normatif, bahan hukum tersebut terdiri dari bahan hukum primer (peraturan perundang-undangan, yurispridensi, traktat, perjanjianperjanjian keperdataan para pihak, dan sebagainya) serta bahan hukum sekunder (buku-buku ilmu hukum, jurnal ilmu hukum, laporan penelitian ilmu hukum, artikel ilmiah hukum dan bahan seminar, lokakarya dan sebangainya).

2. Pendekatannya Yuridis Normatif, yaitu dalam pengkajian atau penelitian untuk menjelaskan hukum tidak diperlukan dukungan data atau fakta sosial, jadi untuk menjelaskan hukum atau mencari makna dan member nilai akan hukum tersebut hanya digunakan konsep hukum dan langkah-langkah yang ditempuh adalah langkah normatif. ${ }^{8}$

3. Menggunakan Metode Interprestasi, untuk menjelaskan atau memaparkan hukum tersebut, metode interprestasi yang digunakan terdiri dari interprestasi gramatikal, interprestasi sistematis, interprestasi historis, interprestasi perbandingan hukum, interprestasi antisipasi dan interprestasi ideologis.

4. Analisisnya, memiliki kekhusussan tersendiri yaitu dalam melihat apakah syaratsyarat normatif dari hukum sudah terpenuhi atau belum sesuai dengan ketentuan dan bangunan hukum itu sendiri.

5. Tidak Menggunakan Statistik, hal tersebut disebabkan karena penelitian hukum normatif merupakan penelitian atau pengkajian yang sifatnya murni hukum.

6. Teori Kebenarananya Pragmatis, artinya dapat bermanfaat secara praktis dalam kehidupan masyarakat.

7. Sarat Nilai, artinya ada pengaruh dari subyek, sebab menurut pandangan para penganut hukum normatif justru dengan adanya pengaruh penilaian itulah sifat spesifik dari ilmu hukum normatif dapat diungkap.

\section{B. Teknik Pengumpulan Data}

Teknik pengumpulan data yang digunakan penulis adalah studi kepustakaan yaitu merupakan teknik pengumpulan data dengan cara mengumpulkan data dari buku-buku yang sesuai dengan permasalahan yang diangkat dalam penelitian ini. ${ }^{9}$

1. Data Primer ${ }^{10}$

Cara pengumpulan data primer yaitu dengan mempelajari dan mengkaji terlebih dahulu Peraturan Pemerintah (PP) Nomor 24 tahun 1997 Tentang

\footnotetext{
${ }^{6}$ Bahder Johan Nasution, Metode Penelitian Ilmu Hukum, Penerbit Mandar Maju, Jambi, 2008, Cet I, hal 86

${ }^{7}$ Ibid

${ }^{8}$ Ibid, hal 87

${ }^{9}$ Zainuddin Ali, Metode Penelitian Hukum, Sinar Grafika, Jakarta, Cet I, 2009, hal 24

${ }^{10}$ Soejono Soekanto, Sri Mamudji, Penelitian Hukum Normatif (Suatu Tinjauan Singkat), Rajawali Pers, Jakarta, 2010, hal 13
} 
Pendaftaran Tanah dan Peraturan Menteri Negara (Permeneg) Agraria / Kepala Badan Pertanahan Nasional Nomor 3 Tahun 1997, Tentang Ketentuan Pelaksanaan Peraturan Pemerintah (PP) 24 Tahun 1997, Tentang Pendaftaran Tanah.

2. Data Sekunder ${ }^{11}$

Adalah data yang diperoleh langsung dari lokasi penelitian, serta responden yang memberikan informasi kepada penulis, hasil penelitian tersebut merupakan data pendukung terhadap penulisan ini, data sekunder juga memberikan penjelasan mengenai bahan hukum primer yang diperoleh dari, rancangan undangundang, hasil-hasil penelitian, hasil karya dari kalangan hukum, dan sebagainya

3. Data Tersier ${ }^{12}$

Adalah bahan-bahan yang memberikan petunjuk maupun penjelasan terhadap bahan-bahan hukum primer dan sekunder, misalnya kamus, ensiklopedi, dll.

\section{Analisa Data}

Analisa data ini dilakukan dengan cara studi dokumentasi yaitu mempelajari peraturan-peraturan yang menjadi objek penelitian yang dipilih dan himpunan berdasarkan azas hukum, kaidah hukum dan ketentuan hukum positif yang mendasarinya.

Hal inilah yang kemudian sangat membedakan antara penelitan Yuridis Normatif dengan penelitian Yuridis Empiris, dalam pengakajian hukum normatif langkah atau kegiatan melakukan analisisnya mempunyai sifat yang sangat spesifik atau khusus, kekhususannya disini bahwa yang dilihat adalah apakah syarat-syarat normatif dari hukum sudah terpenuhi atau belum sesuai dengan ketentuan dan bangunan hukum itu sendiri. ${ }^{13}$

\section{PEMBAHASAN}

\section{Peran Pemerintah Dalam Menertibkan Sistem Pertanahan Di Indonesia}

Selain gencar melaksanakan sosialisasi atau penyuluhan-penyuluhan terkait perndafataran tanah, Pemerintah dalam hal ini Badan Pertanahan Nasional juga melaksanakan beberapa program untuk mendukung pelaksanaan pendaftaran tanah tersebut, dalam rangka tercapainya tertib administrasi di bidang pertanahan. Diantara program yang sudah dijalankan oleh Badan Pertanahan Nasional adalah Proyek Operasi Nasional Agaraia (PRONA) dan Layanan Rakyat Untuk Sertifikasi Tanah (LARASITA).

1. Proyek Operasi Nasional (PRONA)

a. Pengertian Proyek Operasi Nasional Agraria (PRONA)

Dikemukakan oleh Dr. Sunarjati Hartono, sehubungan dengan perkembangan-perkembangan dalam kehidupan masyarakat dan persoalan yang timbul ;

\footnotetext{
${ }^{11}$ Ibid

${ }^{12}$ Ibid

${ }^{13}$ Bahder Johan Nasution, Op Cit, hal 87
} 
Bahwa tanah bagi orang Indonesia merupakan masalah yang paling pokok dapat pula kita konstantir dari banyak perkara perdata maupun pidana yang diajukan ke pengadilan yang berkisar sekitar suatu sengketa tanah. Boleh dikatakan $90 \%$ dari perkara waris menyangkut soal tanah dan rumah belum lagi dihitung perkara piutang dimana tanah menjadi jaminan utang serta perkara penganiayaan, pencurian atau perbuatan melawan hukum yang bermula pada sengketa tanah. Dari banyak perkara-perkara yang menyangkut tanah dapat dilihat bahwa tanah yang sentral dalam kehidupan dan perekonomian yang bersifat agraris. ${ }^{14}$

Keadaan yang demikian itulah yang dikhawatirkan oleh pemerintah umumnya masyarakat yang bersangkutan, maka dari itu dengan Proyek Operasi Nasional Agraria (Prona) ini diharapkan keadaan yang demikian itu dapat diatasi dengan penuh pengertian dan kesadaran masyarakat.

Pada dasarnya Proyek Operasi Nasional Agraria (Prona) ditekankan pada masyarakat dengan ekonomi lemah, sedangkan bagi masyarakat yang tidak mampu atau kurang mampu mereka dibebaskan dari biaya (pasal 19 ayat 4 Undang Undang Pokok Agraria). Kerja Proyek Operasi Nasional Agraria (Prona) meliputi ;

1) Pensertifikatan massal.

2) Penyuluhan-penyuluhan hukum tentang keagrariaan.

3) Menginventarisasikan sengketa-sengketa pertanahan.

Petugas lapangan terdiri dari Kepala Kantor Agraria Kotamadya dan stafnya, mereka diberangkatkan ke lokasi yang ditentukan dan membuat pos Proyek Operasi Nasional Agraria. Di pos ini berlangsung kegiatan penyelesaian permohonan pemilik tanah, pengukuran, pemetaan dan pembuatan gambar, pengesahan dan penyelesaian surat-surat untuk penerbitan sertifikat, penyelesaian sengketa tanah dan penyelesaian risalah pemeriksaan tanah, semua kegiatan itu diupayakan agar jauh dari persengketaan.

Petugas agraria juga memberikan penyuluhan-penyuluhan bergerak ke lokasi yang ditetapkan misalnya sekolah, tempat ibadah, pasar, dll. Penyuluhan diberikan dan sekaligus dibagikan formulir petunjuk tata cara mengajukan permohonan.

Setelah selesai dilakukan pengukuran langsung dibuatkan gambar tanah, tempatnya di pos-pos yang telah ditentukan bisa dib alai desa, gedung serbaguna, rumah penduduk, atau ditenda-tenda yang telah didirikan sebelumnya. Bila semua sudah selesai tinggal gerakkan satuan tugas administrasi, mereka menyelesaikan segala urusan administrasi sampai terbit dan diserahkannya sertifikat kepada pemohon.

Proyek Operasi Nasional Agraria (Prona) yang berlaku mulai 15 Agustus 1981 yang dikeluarkan melalui Keputusan Menteri Dalam Negeri Nomor 189 tahun 1981 dengan penjelasan sebagai berikut ;

${ }^{14}$ Sunarjati Hartono, Beberapa Pemikiran ke Arah Pembaharuan Hukum Tanah, Penerbit Alumni, Bandung, 1978, hal 8 
1) Pembentukan Proyek Operasi Nasional Agraria (selanjutnya disebut proyek) adalah merupakan salah satu upaya dalam melaksanakan Garisgaris Besar Haluan Negara (Tap MPR No IV/MPR/1978) dan tertib administrasi pertanahan sebagaimana yang telah ditetapkan oleh pemerintah. Tujuan Proyek adalah untuk menumbuhkan kesadaran hukum masyarakat dalam bidang pertanahan, sebagai upaya untuk berpartisipasi dalam menciptakan stabilitas sosial politik serta pembangunan di bidang ekonomi.

2) Tugas Proyek adalah ;

a. Melaksanakan suatu program pensertifikatan tanah secara massal di Indonesia untuk memberikan jaminan kepastian hukum bagi penguasaan dan pemilikan tanah sebagai tanda bukti yang kuat.

b. Melaksanakan pemeriksaan dan penelitian terhadap kasus-kasus tanah yang berupa sengketa yang bersifat strategis dan menyelesaikannya secara tuntas. ${ }^{15}$

b. Objek Pensertifikatan Proyek Operasi Nasional Agraria (Prona)

1) Diutamakan desa-desa yang sudah ada peta wilayah atau situasinya, misalnya ;

a) Sudah ada peta potret.

b) Sudah ada peta yang dbuat berdasarkan desa demi desa.

c) Sudah ada peta situasi dalam rangka pembuatan sertifikat secara rutin.

2) Bila di suatu Kabupaten/Kotamadya belum ada desa yang mempunyai peta wilayah berdasarkan pengukuran desa demi desa dipilih desa atau daerah yang telah mempunyai peta dari instansi lain atau peta-peta lain yang akan memudahkan gambar situasi.

3) Hindarkanlah daerah-daerah yang terlalu banyak sengeketa, yang memungkinkan tak dapat diselesaikan dengan segera. ${ }^{16}$

Untuk menentukan apakah daerah tersebut terkena Proyek Operasi Nasional Agraria, maka syarat-syarat yang harus dipenuhi adalah ;

1) Penentuan lokasi proyek untuk wilayah Kabupaten/Kotamadya harus dikaitkan dengan ruang lingkup proyek. Dalam melaksanakan proyek, pembagian kerja tetap dilakukan secara fungsional sesuai dengan bidang tugasnya masing-masing agar dengan demikian tetap terjamin adanya kebenaran formil dan materil sesuai dengan ketentuan yang telah ditetapkan, adapun urutan prioritas sebagai berikut ;

a) Ditetapkan secara berkelompok terutama untuk pensertifikatan tanah di daerah-daerah yang penguasaan atau pemilikan tanahnya terkena ketentuan Landreform baik yang ditujukan pada tanah-tanah yang masih menjadi hak bekas pemilik lama maupun yang telah diretribusikan kepada para penggarap.

b) Ditetapkan secara berkelompok untuk daerah-daerah penerima transmigran atau daerah-daerah Resttlement.

c) Ditetapkan di daerah-daerah yang tanahnya mempunyai potensi produksi bahan pokok yang cukup untuk dikembangkan.

\footnotetext{
${ }^{15}$ Surat Keputusan Menteri Dalam Negeri Nomor 189 Tahun 1981 Tentang Proyek Operasi Nasional Agraria

${ }^{16}$ Djoko Prakoso, Budiman Adi Purwanto, Eksistensi Prona Sebagai Pelaksanaan Mekanisme Fungsi Agaria, Ghalia Indonesia, Jakarta, 1985, hal 69
} 
d) Ditetapkan secara berkelompok pada dan mempunyai potensi yang cukup besar untuk dikembangkan.

e) Dipilih mengenai tanah-tanah sengketa yang bersifat strategis dan dapat diselesaikan secara tuntas.

2) Tiap-tiap Kabupaten/Kotamadya supaya ditetapkan lokasi proyek di daerah-daerah masing-masing dan harus dapat menerbitkan sertifikat tanah sebanyak-banyaknya.

3) Dengan menentukan lokasi pensertifikatan massal sebagaimana yang dimaksud dalam poin 1 dan 2, sudah barang tentu tidak termasuk lokasilokasi proyek lain yang tidak dijangkau oleh program Proyek Operasi Nasional Agraria (Prona). ${ }^{17}$

Dalam rangka melaksanakan Proyek Operasi Nasional Agraria ini telah tersusun peraturan pemerintah mengenai aturan biaya-biaya yang diperlukan dalam rangka Proyek Operasi Nasional Agraria, dan untuk memenuhi keinginan masyarakat dalam mendapatkan sertifikat tanah, perlu adanya peningkatan pelayanan kepada masyarakat dari pihak agraria yang terpadu mencakup semua fungsi keagrariaan.

Dengan demikian para pemilik tanah dapat mengurus sertifikat tanahnya secara mudah, cepat dan murah, khususnya dari masyarakat ekonomi lemah untuk menyelesaikan atau mengurus sertifikat hak atas tanahnya maka perlu diadakan penetapan biaya yang ringan terhadap pemberian hak-hak atas tanah negara maupun penegasan tanah-tanah hak adat yang dijadikan lokasi atau obyek Proyek Operasi Nasional Agraria.

Sasaran yang hendak dicapai oleh pemerintah dengan pelaksanaan program Prona adalah selain untuk menciptakan tertib administrasi pertanahan juga untuk pelaksanaan pemusatan pendapatan serta peningkatan kesejahteraan masyarakat, pemusatan pendapatan akan tercapai apabila ada usaha peningkatan pandapatan pada sebagian besar anggaran rakyat, yaitu dengan jalan mengadakan pengolahan-pengolahan terhadap tanah sesuai dengan anjuran pemerintah dengan melalui penyuluhan-penyuluhan dan anjuran untuk menanamkan bibit tanaman yang telah ditunjuk, guna untuk meningkatkan hasil produksi tersebut.

Telah kita sadari bahwa terhadap masalah pertanahan realitanya pada dewasa ini menjadi problem dan telah banyak masalah pertanahan ini yang menimbulkan perselisihan antara pihak-pihak yang bersangkutan. Oleh karena itu penanganan tugas keagrariaan dilaksanakan dengan cara kerja yang konsepsional dan berprogram meliputi semua fungsi yang ada yaitu tata guna tanah, fungsi Landreform, pengurusan hak-hak atas tanah dan pendaftaran tanah yang didukung oleh administrasi yang mantap.

2. Layanan Rakyat Untuk Sertifikasi Tanah (LARASITA)

Layanan Rakyat Untuk Sertifikasi Tanah (LARASITA) adalah Pola Pelayanan Pertanahan yang secara aktif dilakukan oleh BPN RI bagi masyarakat dalam pengurusan pertanahan untuk memberikan keadilan bagi masyarakat, mempercepat proses, meningkatkan cakupan wilayah dan untuk menjamin pengurusan pertanahan tanpa perantara dengan cara mendekatkan pelayanan BPN

${ }^{17}$ Petunjuk Pelaksanaan PRONA, Dirjen Direktorat Agararia, Jakarta, 4 September 1981, hal 6 
RI secara langsung kepada masyarakat melalui Kantor Pertanahan Bergerak (mobile office). ${ }^{18}$

Larasita adalah produk baru pelayanan pertanahan yang dikembangkan oleh Kantor Pertanahan untuk mendekatkan pelayanan ke masyarakat. Secara mudah dapat dikatakan bahwa Larasita adalah program pelayanan masyarakat di bidang pertanahan yang dilakukan dengan cara membawa front office ke tempat tinggal masyarakat. Masyarakat tidak perlu mengunjungi kantor pertanahan, cukup menunggu di desanya saja karena Larasita secara terjadwal akan mengunjungi masyarakat yang berada di pelosok-pelosok desa yang membutuhkan pelayanan pertanahan. ${ }^{19}$

Larasita dikembangkan dari motivasi untuk lebih mendekatkan BPN dengan masyarakat, sekaligus mengubah paradigma pelayanan BPN dari "menunggu/pasif" menjadi "menjemput/aktif" mendatangi masyarakat secara langsung.

Larasita menjalankan tugas pelayanan sertifikasi tanah di manapun target kegiatan berada (Kantor Pertanahan Bergerak/mobile office). Dengan Kantor Bergerak tersebut akan memberikan ruang interaksi antara aparat BPN/Kantor Pertanahan dengan masyarakat sampai tingkat Kecamatan, Desa/Kelurahan, RT/RW diseluruh wilayah kerja, terutama pada wilayah yang jauh dari Kantor Pertanahan.

Adapun Tujuan dan Manfaat Larasita ${ }^{20}$

a. Tujuan Larasita adalah ;

1) Membangun kepercayaan masyarakat terhadap kinerja Badan Pertanahan Nasional Republik Indonesia.

2) Mendekatkan pelayanan pertanahan ke semua masyarakat, terutama yang secara geografis mempunyai kendala untuk mendatangi Kantor Pertanahan.

3) Menghilangkan peran pihak ketiga dalam pelayanan Pertanahan dan memotong mata rantai pengurusan sertifikat tanah.

4) Mengurangi terjadinya konflik pertanahan.

5) Meningkatkan target sertifikasi bidang tanah secara nasional.

6) Meminimalkan bias informasi pertanahan ke masyarakat.

b. Manfaat Larasita adalah ;

1) Masyarakat secara langsung menikmati pelayanan yang adil, terukur, jelas, terang, mudah dan bertanggung jawab.

2) Memberikan kepastian hukum dan proses serta memudahkan bagi masyarkat yang hendak melakukan sertifikasi tanah.

Larasita sebagai Kantor Pertanahan Bergerak memberikan pelayanan kepada masyarakat melelui prosedur Pendaftaran Tanah Pertama kali baik secara perorangan maupun secara kolektif melalui Desa/Kelurahan dengan dilampiri Daftar Nominatif calon peserta.

Jumlah peserta tidak dibatasi, namun dibatasi dengan batas waktu pendaftaran di lapangan sampai dengan pukul $12.00 \mathrm{Wib} / \mathrm{Wita}$.

Masyarakat/peserta tidak perlu datang ke Kantor Pertanahan selama proses berlangsung, cukup menunggu di Desa/Kelurahan dan petugas Larasita yang akan mendatangi peserta untuk menerima berkas-berkas permohonan

\footnotetext{
${ }^{18}$ Ibid

${ }^{19}$ Badan Pertanahan Nasional Republik Indonesia (BPN-RI), Aplikasi Pemetaan Kantor

Pertanahan LOC Gravikal Versi 4.2, juga ditulis oleh Maria Iriana Puji Lestari, 6 Juli 2010

${ }^{20}$ Ibid
} 
sertifikasi dan biaya.

Sertifikat yang sudah selesai akan diserahkan petugas Larasita ke Desa/Kelurahan domisili peserta. Penggunaan tanah diutamakan untuk rumah tinggal dan tidak dalam sengketa serta belum bersertifikat.

\section{PENUTUP}

\section{A. Kesimpulan}

Upaya yang dilakukan oleh pemerintah dalam hal ini Badan Pertanahan Nasional (BPN) untuk mendukung terlaksananya program pendafatarn tanah adalah dengan Program Nasional Agraria (PRONA) dan Layanan Rakyat Sertifikasi Tanah (LARASITA).

\section{DAFTAR PUSTAKA}

\section{Literatur :}

Ali Zainuddin, Metode Penelitan Hukum, Sinar Grafika, Jakarta, 2009

E. Utrecht, Pengantar Hukum Administarasi Negara Indonesia, Pusataka Tinta Mas, Surabaya, 1988

Harsono Boedi, Hukum Agraria Indonesia, Djambaran, Jakarta, 2003

Hartono Sunarjati, Beberapa Pemikiran ke Arah Pembaharuan Hukum Tanah, Penerbit Alumni, Bandung, 1978.

Hermit Herman, Cara Memperoleh Sertifikat Tanah (Tanah Hak Milik, Tanah Negara, Tanah Pemda dan Balik Nama), Mandar Maju, Bandung, Cet II, 2009, hal 31

HR Ridwan, Hukum Administrasi Negara, Raja Grafindo Persada, Jakarta, 2006

K. Saleh Wantjik, Hak Anda Atas Tanah, Ghalia Indonesia, Jakarta, 1997

Nasution Johan Bahder, Metode Penelitian Ilmu Hukum, Mandar Maju, Bandung, 2008

P. Parlindungan, Pendaftaran Tanah Di Indonesia, Mandar Maju, Bandung, Cet I, 1999.

Prakoso Djoko, Purwanto Adi Budiman, Eksistensi Prona Sebagai Pelaksanaan Mekanisme Fungsi Agraria, Ghalia Indonesia, Jakarta, 1985.

S.A de Smith, Constituonal and Administration Law, Second Edition (EnglandPeguin Edication), 1973

Santoso Urip, Hukum Agraria dan Hak-Hak Atas Tanah, Kencana, Jakarta, 2007

Sangsun SP Florianus, Tata Cara Mengurus Sertifikat Tanah, Visimedia, Jakarta, 2007 
Soekanto Soejono, mamudji Sri, Penelitian Hukum Normatif (Suatu Tinjauan Singkat), Rajawali Pers, Jakarta, 2010,

Soedjono, Abdurrahman, Prosedur Pendaftaran Tanah (Tentang Hak Milik, Hak Sewa, dan Hak Guna Bangunan), Rhineka Cipta, Cet III, 2008.

Supriadi, Hukum Agraria, Sinar Grafika, Jakarta, Cet II, 2008.

Thalib Sajuti, Hubungan Tanah Dengan Masyarakat Indonesia, Djambaran, Jakarta, 2004

\section{Peraturan Perundang-undangan :}

Amandemen Undang-undang Dasar 1945

Undang-undang Nomor 5 tahun 1960, Tentang Undang-undang Pokok Agraria (UUPA)

Peraturan Pemerintah (PP) Nomor 24 tahun 1997, Tentang Pendaftaran Tanah

Peraturan Menteri Negara (Permeneg) Agraria / Kepala Badan Pertanahan Nasional Nomor 3 Tahun 1997, Tentang Ketentuan Pelaksanaan Peraturan Pemerintah (PP) 24 Tahun 1997, Tentang Pendaftaran Tanah.

Nomor 18 Tahun 2009, Tentang Larasita Badan Pertanahan Nasional Republik Indonesia

Surat Keputusan Menteri Dalam Negeri (Kepmendagri) Nomor 22 Tahun 1981, Tentang Besar Pungutan Biaya Dalam Rangka Pemberian Sertifikat yang Menjadi Obyek Operasional Nasional Agraria (PRONA.)

Tentang Proyek Operasi Nasional Agaria (PRONA.) 
